\title{
Writing Conservation: The impact of text on conservation decisions and practice
}

\author{
Elizabeth Pye \\ University College London
}

\begin{abstract}
Introduction
The purpose of conservation is to investigate and preserve objects, and the information they hold, and to make both accessible for study and enjoyment now and in the future. This paper focuses on conservation as a means of interpreting meaning, in that decisions on conservation procedures depend on assessing the material, the significance and the intended future use of an object. The presence of writing frequently adds significance and possible uses which must be taken into account. It also has a considerable influence on conservation decisions; in extreme cases conservators may be faced with a choice between long-term preservation without investigation of written text, or material alteration (and possible loss of some other potentially valuable evidence) in order to retrieve text. This chapter also discusses the advent of digital imaging which has introduced exciting new possibilities for elucidation and preservation of, and access to, written text.
\end{abstract}

\section{Conservation as a Method of Study}

Conservation is usually seen as straightforward process of treating objects to remedy existing damage and to prevent further deterioration. But there are layers of investigation and assessment of each object which support conservation, and are essential to achieving a satisfactory outcome (and which, at the same time, provide information of wider interest). Also essential for a satisfactory outcome is to establish the aims of conservation and these depend largely on the future use of the object. Thus, if there is visible writing, or the potential to reveal writing, on an object, and

\section{How to cite this book chapter:}

Pye, E. 2013. Writing Conservation: The impact of text on conservation decisions and practice. In: Piquette, K. E. and Whitehouse, R. D. (eds.) Writing as Material Practice: Substance, surface and medium. Pp. 319-333. London: Ubiquity Press. DOI: http://dx.doi.org/10.5334/bai.p 
the future use focuses on studying and displaying this writing, conservation will normally focus on making sure the text is rendered legible and durable, as far as this is possible.

\section{Objects and Documents}

Most conservators see objects as documents, and the investigative processes we use as a way of 'reading' objects. Ironically, books and documents are not often seen as multidimensional objects, thus the concept of the book as an object encompasses all the material aspects such as paper, inks, binding, etc. This has become the focus of specialist studies (see, for example, Centre for the History of the Book, University of Edinburgh, or Centre for the Study of the Book, Bodleian Library Oxford). This situation is partly shaped by the way objects and documents are used. Libraries preserve their holdings for their continued original use (reading) and for relatively ready access by the public, whereas museums limit the use (and particularly the original use) of their collections and tend to focus on long-term preservation. Thus, in some ways the approach to care of library material is akin to regular repair and maintenance aimed at keeping books and documents in working order, whereas the approach in museums is to conserve objects through restricting direct access, except for specific educational and research purposes. Of course, major libraries also hold historically valuable written material which is treated much like museum objects, with an emphasis on conservation, and on research aimed at adding to the sum of information about the individual item, as well as about writings in general.

\section{Principles Governing Conservation Practice}

Behind much conservation thinking lies the concept of the biography of an object (Appadurai 1986; Gosden and Marshall 1999). Each object may have gone through many changes in its socalled 'life', each of which may have left some kind of trace. These traces may be the results of material changes, such as corrosion of metals, or caused through human agency, such as the wear marks induced by use. Thus objects contain a range of material and conceptual evidence and can be seen as embodied technical and social history, or documents waiting to be read. Much of this information remains latent until elucidated during conservation.

A key conservation principle is that understanding objects is an essential first step in reaching conservation decisions. Conservators examine ('read') objects in great detail. Their assessment and diagnosis of the objects' conservation needs depends on: investigation of material(s) (thus of technologies); condition (thus of deterioration, signs of use, modification, repair or recycling); significance (thus of history, and of meaning assigned to these objects by different past and present individuals and groups); and future use (thus of potential to make new or further meanings). This assessment must involve communication and collaboration with other scholars and interest groups, particularly when developing an understanding of significance. It will also involve laboratory investigation such as microscopic examination and materials testing which may reveal a range of information not accessible through normal visual examination.

Another of the principles of conservation is that procedures should not affect the identity - the materials or the various possible meanings - of the object. In the past this was coupled with the principle of reversibility: that any changes induced by conservation could be reversed if necessary, thus supporting the aim of minimising change to the object. However, the principle of reversibility now remains only as an attractive idea, since it is widely acknowledged to be impossible to put into practice effectively (Appelbaum 1987; Muñoz Viñas 2005: 183-188).

The principle of minimum intervention (which to some extent replaces reversibility) acknowledges that conservation inevitably changes either the material (e.g. through cleaning) or the 
perception of an object (e.g. through analysis or restoration processes) or possibly both (Muñoz Viñas 2009). So the aim is to minimise change by doing as little as possible to the object provided it is enough to achieve a satisfactory conservation result. The intention is that this approach will not only limit change to the materials and/or distortion of the meaning(s), but that it should allow for further investigation in the future, and if necessary, future retreatment. To apply this principle effectively it is essential to understand the object well enough to be confident about where (and where not) to intervene with conservation treatment.

\section{Values Assigned to Objects}

The identity which conservation aims to safeguard can be seen as the sum of the values assigned to the object. Values are accumulated (and lost) throughout the life of the object. Value may change when an object is studied and reinterpreted, and it is quite possible for apparently insignificant, mass-produced objects to be assigned new value, perhaps because of changes in fashion or because of a link with a significant person or event.

One set of values is related to the material character of an object. A wide range of organic and inorganic materials has been used to provide surfaces for writing, some of them more durable than others; the character and working properties (e.g. hardness, ductility) provide insight into the eventual form of the writing (Brown 1998). The Babylon exhibition, held at the British Museum in 2008 (Finkle and Seymour 2008), included the display of large numbers of clay writing tablets which demonstrated very clearly not only the technique of impressing a writing tool into soft clay, but the remarkable survival of the tablets themselves (though some or many of these may have been made more durable by baking as part of conservation treatment - see below). In the case of books, the form of the book and the style of the binding may have technological, historical and aesthetic value, and may carry important information about previous ownership (Foot 1984). Although the wording of a text may be highly significant on its own, preserving the material original means that there remains the potential to learn more from it in the future. In addition to text, documents may carry other important material evidence, such as seal impressions or signatures, which indicates the text's authenticity and legal standing.

Complementing the material values assigned to an object are the meanings which may be attached to it. Obliterated text on a coin or medal may be frustrating if the aim is to identify it, but it may add other values by indicating how long the coin may have been in circulation, or how lovingly a medal may have been polished. Here, loss of material may mean gain in another aspect of meaning. The material and form of writing has meaning, e.g. for early printed text, both the uneven layout and the heavy impressions left in the page indicate the difficulties of regulating early hand printing, especially if cheaply produced (Figure 1). Handwriting provides an insight into the person: the skill of a medieval scribe seen in the Domesday book (National Archives 2009); the apparent energy and confidence of John Stewart Mill's handwriting, as seen in the documents displayed in the exhibition entitled Taking Liberties held at the British Library in 2009 (Ashley 2008).

\section{The Presence of Text and its Effect on the Perceived Values of Objects}

How does the presence of writing on an object affect the balance of the material and conceptual values, and consequent conservation choices? The role of the text in relation to the material and function of the object has an important impact on its relative value. There are perhaps three levels at which the relationship of text and material can be considered. The first is where the function of the object is purely to provide written information, and the material feature is regarded mainly as a carrier for the text (e.g. newspaper). The second involves text which is a significant feature of 


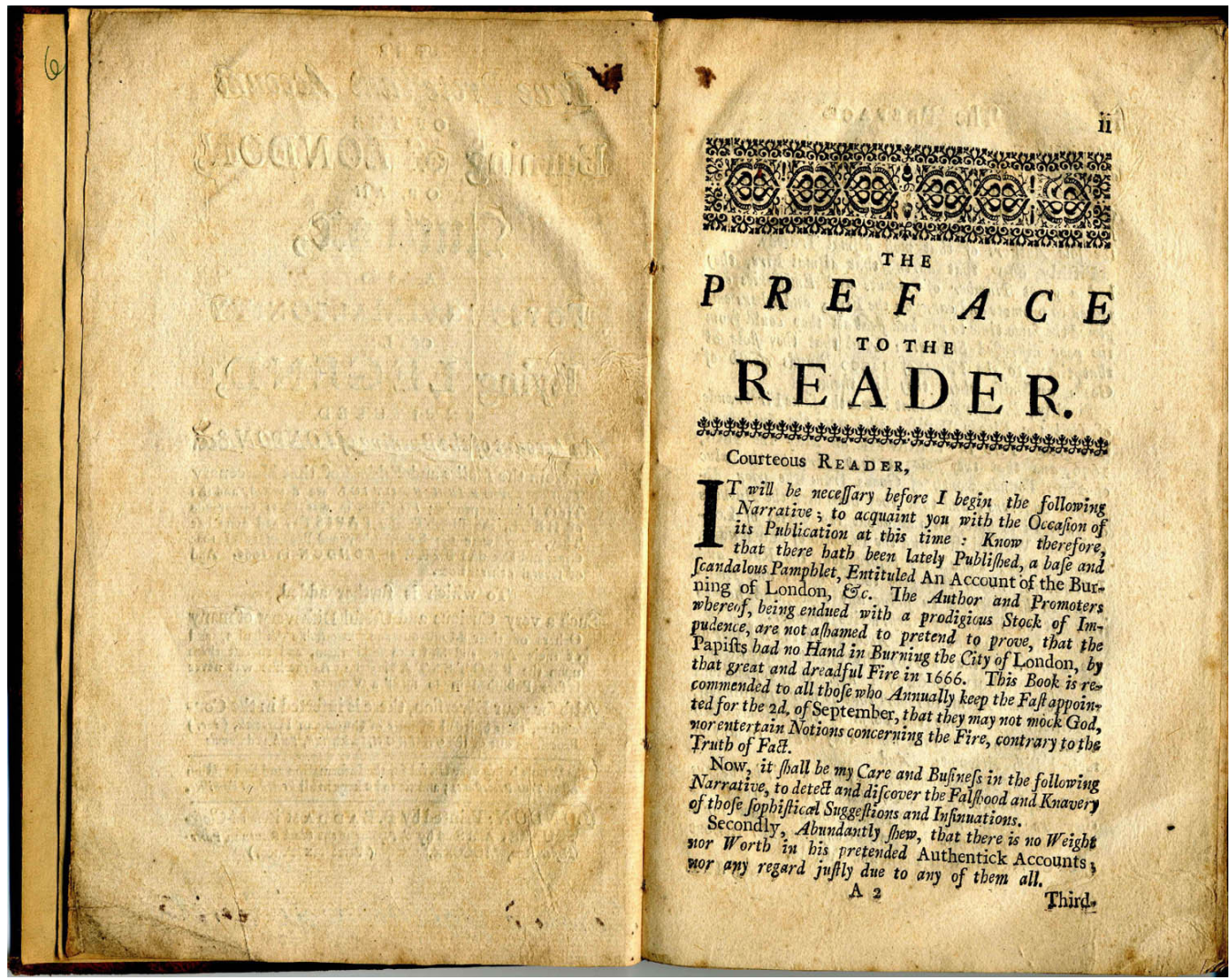

Figure 1: Book of tracts, dated 1720, about the causes of the Fire of London (1666). The uneven layout and the heavy impressions left in the page indicate the unregulated nature of some early (and probably cheap) printing. Photograph by Nick Balaam.

the function of the object, but where the material, too, is important, e.g. the denomination and other details on a coin as well as the metal or alloy from which the coin is made (Oddy 1980: 31 ), or cups awarded as prizes where the dedicatory inscriptions are an important feature, but so are the material and form of the cup. Figure 2 shows two pewter tankards awarded as prizes during the $19^{\text {th }}$ century; the form and material indicate a comparatively modest status, and so do the inscriptions (one was awarded as a consolation prize in an athletics event!). The third type of relationship of text with material involves writing which indicates quality or source but does not affect the function of the object, e.g. makers' marks on tools or ceramics, shelf marks on books. In this case the text is only one feature of the object as a whole, and normally will not affect the way the object is used, though it may impart historical information to the understanding of that object (Caple 2006: 56-59).

In practice, because of its evidential value, the presence (or assumed presence), of any form of writing will almost always take priority over other factors during preliminary investigation, and when making conservation decisions. It will be considered important to investigate the surface of any kind of object which would be expected to carry writing (e.g. a coin), to elucidate obscured lettering or to preserve text that is already visible. Figure 3 shows three superficially similar copper alloy coins excavated in the author's garden. Although corroded, it is the visible text which identifies them as a Russian two kopek piece (1840), a South African penny (1898), and a British penny (1907). Once the coins are read it is possible to speculate that the first might have been 


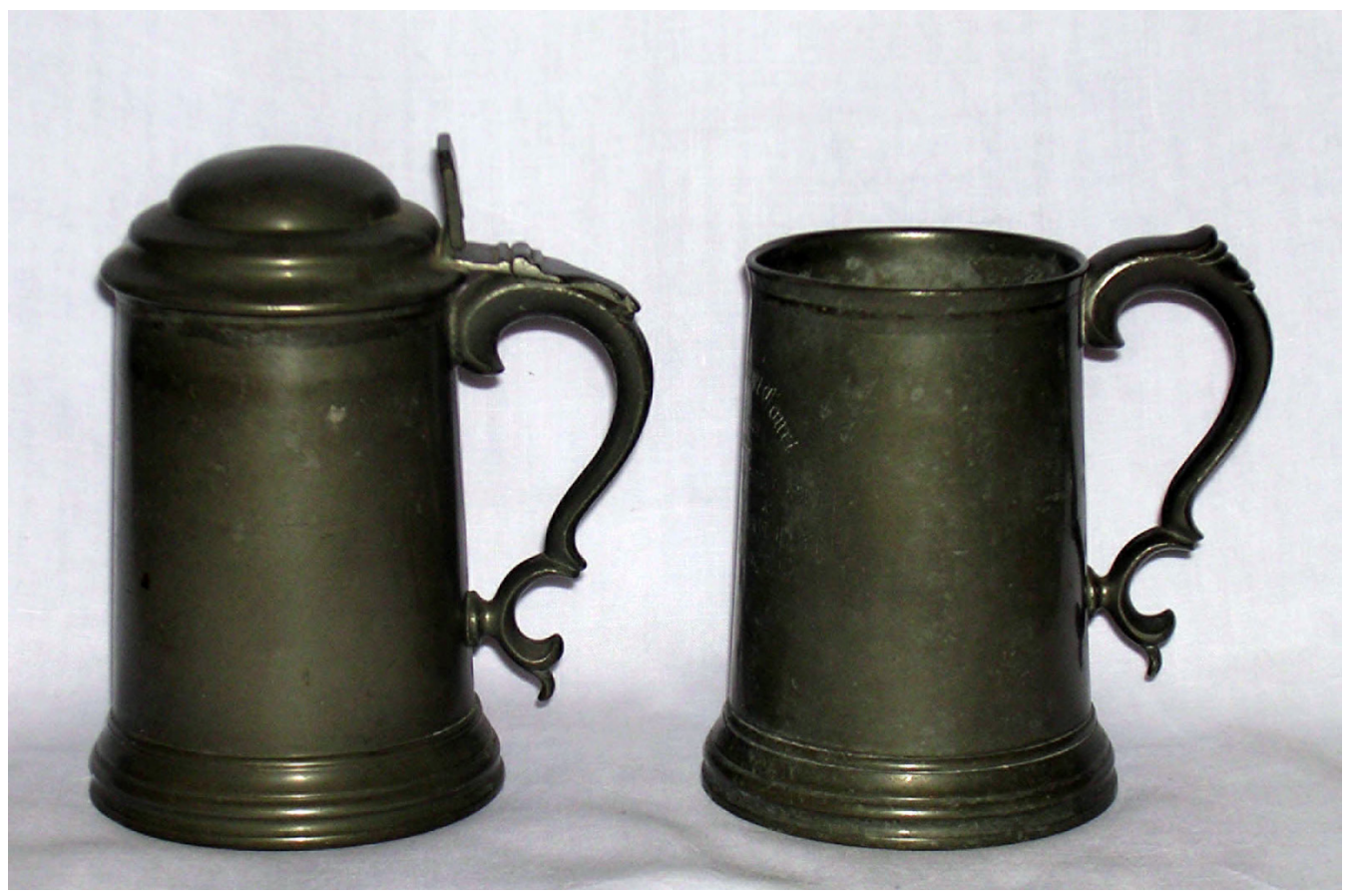

Figure 2: Two pewter tankards awarded as prizes during the $19^{\text {th }}$ century. These were more or less standard-pattern tankards exported throughout the British Empire, then 'personalised' with a suitable inscription. One was awarded in 1865 as a consolation prize in an athletics event in Oxford, and the other in 1872 after a racquets tournament in Hong Kong. Photograph by Nick Balaam.

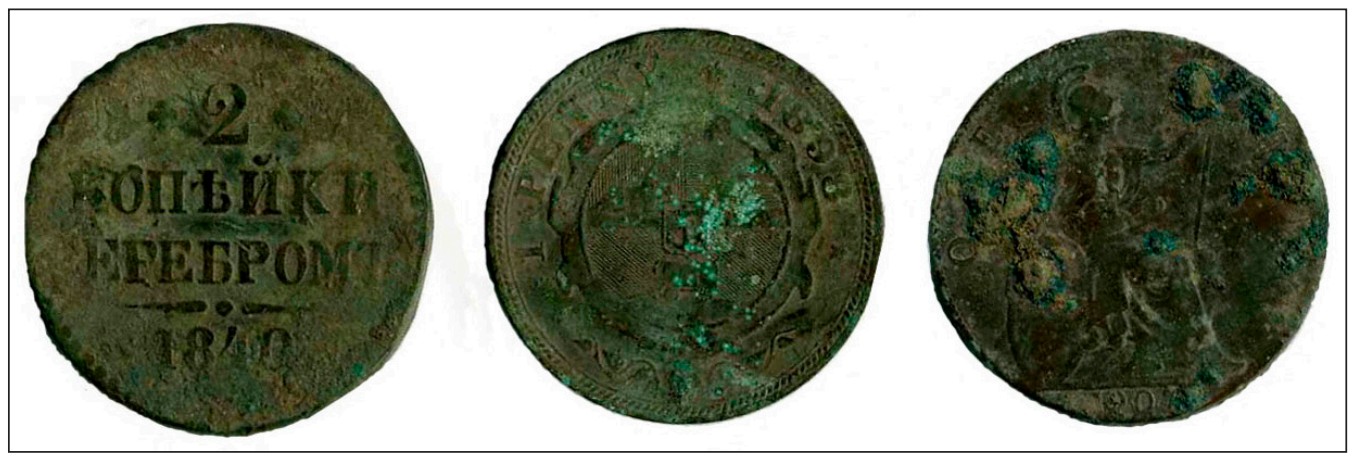

Figure 3: Reverse of three superficially similar copper alloy coins excavated in the author's garden. Although corroded, it is the visible text which identifies them (from left to right) as a Russian two kopek piece (1840), a South African penny (1898), and a British penny (1907). Photograph by Nick Balaam.

brought back to rural Norfolk by a soldier returning after the Crimean War (1853-1856) and the second after the Boer War (1899-1902)!

The investigation may establish not just the letters or words, but how the text was written, e.g. impressed into damp clay, scratched into plaster, formed in the die for a coin, cast or engraved into metal, printed onto paper; it will help to indicate whether the intention was for the text to be 
long-lasting or transitory. It will contribute to understanding the extent to which the text affects the significance of the object as a whole.

\section{Dilemmas in Conservation Practice: Approaches to dealing with text}

Conservation practice ranges from preliminary investigation, through preventive measures, to remedial techniques, and to restoration; it may involve removing a vulnerable object from circulation and replacing it with a replica or surrogate. The conservator is faced with several dilemmas: if an object demonstrates several values, and has clearly gone through a number of changes to condition and meaning, should it be conserved in its current state, or should an attempt be made to regain something of an earlier state (Brooks et al. 1996)? Should a musical instrument, or clock, be conserved so that it can demonstrate its original function of producing sound, or keeping time (this may involve repairing or replacing worn parts), or should it be cleaned of later accretions and stabilised as a static example in a typological sequence, or conserved complete with all the damage resulting from association with a notable event (a bugle used in a famous battle, a clock which went down with the RMS Titanic)?

Should a book be conserved so that the pages can once more be turned safely, or should it be kept in its well-thumbed and disintegrating state to demonstrate prolonged use? Figure 4 depicts an early $18^{\text {th }}$-century Greek and Latin lexicon showing evidence of early $19^{\text {th }}$-century schoolboy use. The structure of the book and the binding are not exceptional and the text is now probably of little practical use, although its age and consequent idiosyncrasies may be of interest. It is the object as a whole including the signs of use and wear, and the annotations (no longer seen, at least by some, as defacement but as adding charm) which provides interesting social evidence. This has been conserved as is, with no attempt to repair (despite its relatively poor condition), in order to demonstrate its history of use and to avoid prioritising any particular aspect. It is simply given good general care to prevent further damage.

The treatment of the lexicon is an example of preventive conservation. This form of conservation is considered the most ethical approach since it involves as little change to an object as possible (Pye 2001: 130; Williams 1997). It aims to conserve both material and meaning, but will not necessarily elucidate concealed text. If the obscuring corrosion on a coin or Roman military diploma is considered stable, these objects could simply be given good storage conditions (preventive conservation), but the text would remain illegible to the naked eye (although it may be possible to detect detail using X-radiography). In practice the perceived significance of the lettering on the coin or the text of the diploma would almost certainly lead to the decision to remove the corrosion. This would enhance legibility but not necessarily improve long-term stability of the metal without further conservation treatment, since a stable corrosion layer will have been disrupted. Thus, the materiality of the writing governs conservation choices, often regardless of the material condition of the object as a whole.

\section{The Drive to Reveal Text}

The requirement to clarify or reveal lettering brings the problem of balancing the benefit of elucidating text with the risk of damage or loss. The discovery, in the mid- $18^{\text {th }}$ century, of a mass of papyrus scrolls at Herculaneum (the Roman town buried by volcanic ash during the eruption of Mount Vesuvius in AD 79) provides a historical example. Ever since their discovery, classical scholars have been understandably eager to read the contents of the scrolls, and extensive efforts had been made to unroll them. The scrolls are partially carbonised and extremely fragile. A successful, but excessively slow, method for unrolling was perfected in the mid- $18^{\text {th }}$ century by 


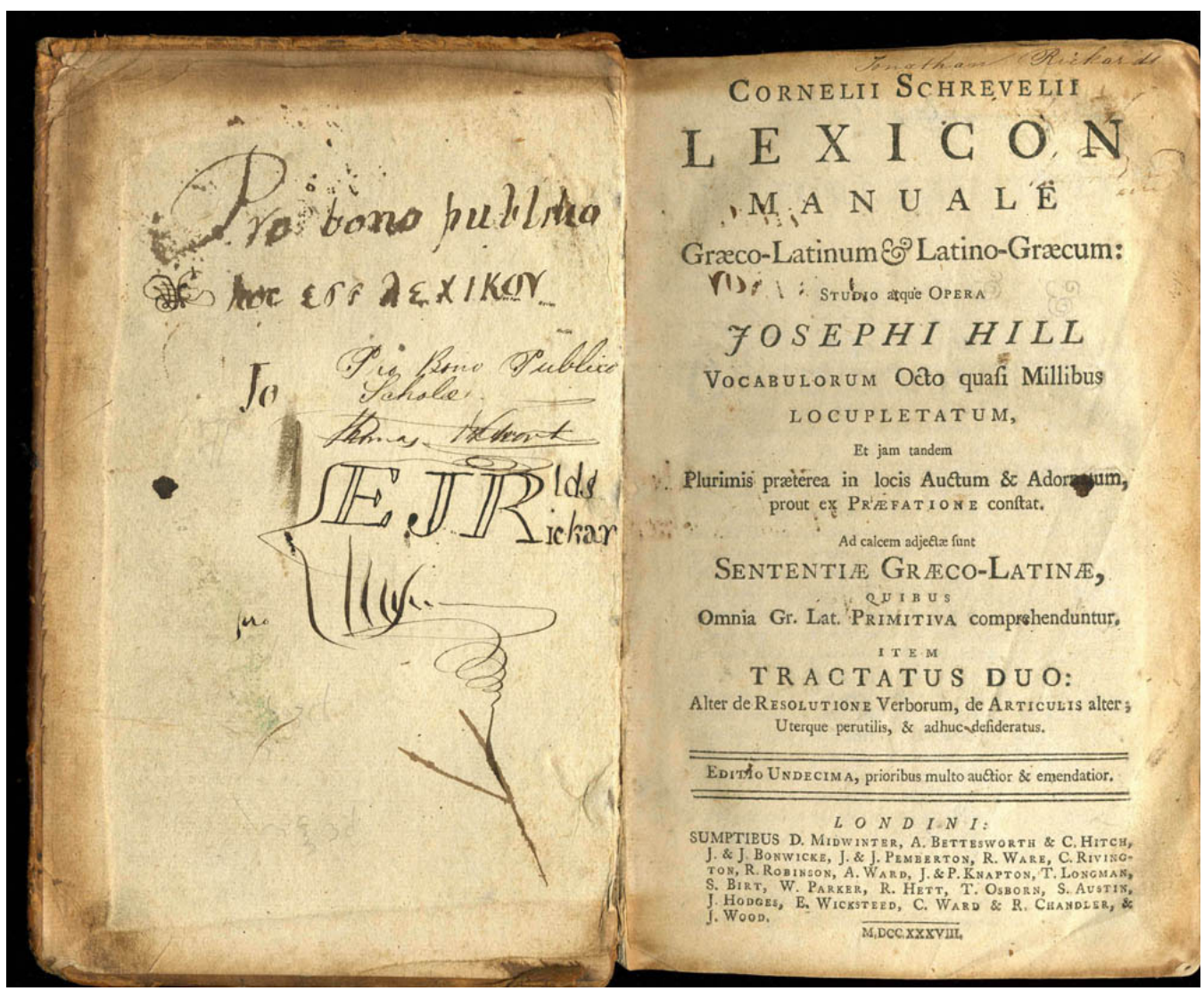

Figure 4: A Greek and Latin lexicon (1738) showing evidence of early $19^{\text {th }}$-century schoolboy annotations. On the covers there are more graffiti and on the end papers there are caricatures (possibly of the teachers?). Photograph by Nick Balaam.

Piaggio, but scholars and scientists (including Sir Humphry Davy - the eminent $19^{\text {th }}$-century chemist) continued to experiment in the hope of finding a better approach (Gilberg 1988). Almost all attempts resulted in failure and apparently very large numbers of the scrolls were lost. However exciting new imaging techniques have now made it possible to elucidate the text on similar scrolls (Baumann et al. 2008; Chabries et al. 2003).

Conservation cleaning is a current example of risking loss of material of an object in order to reveal the materiality of text. This technique is used to remove superficial accretions which may be masking the significance of an object where this is demonstrated by surface detail (e.g. tool marks, decoration, and text). But cleaning is a complex procedure since it may be difficult to distinguish where the informative surface lies (on corroded metals it may lie not beneath, but within the layers of corrosion, Pye 2001: 135). Cleaning may also damage other significant evidence such as remaining traces of paint. Inscriptions cut in stone were frequently coloured but if the traces of pigment are masked by, or mingled with, dirt or deterioration products of the stone they may be removed by ill-judged cleaning. This situation calls for both careful preliminary investigation, and for collaboration with specialists familiar with the inscriptions. Other important technological features may be as difficult to detect and equally vulnerable to cleaning, such as minutely thin layers of silver on Roman debased 'silver' coinage (Vlachou et al. 2003). Thus cleaning (that apparently innocuous, even beneficial, process) is potentially destructive and often controversial. 
Conservation documentation goes some way to preserving evidence through recording, but even meticulous documentation of the stages and effects of cleaning cannot compensate for the removal of evidence and loss of material relationships.

To balance the information gained with the potential for loss of other information, cleaning may focus on selective areas only, or may not be taken through to completion. Excavated coins are cleaned to reveal lettering, mint marks and other detail because of their importance in dating the coin (and, on an archaeological excavation, the context from which it came). This is usually undertaken mechanically as this method provides the most control and the ability to monitor carefully what is being revealed; however, it is a time-consuming process. Thus coins are often only partially cleaned, the process being taken just far enough to gain adequate information for identification (Seeley 1980: 6). Coin hoards present another conservation problem since the coins are often 'welded' together by corrosion. In this case the drive to identify the number, range and date(s) of the coins usually leads to the use of (less controllable but potentially rapid) chemical treatments to separate the coins.

Despite the conservation principles discussed above, a fundamentally irreversible process has been used for over a century to preserve the text on cuneiform tablets made of (usually) unfired, sun-dried clay. Because of the problems of fragility and frequently of damaging and obscuring salts absorbed during deposition, the tablets have been traditionally fired to strengthen them. This makes them more easily handleable for reading and more resistant to salt removal processes, but turns the clay tablets into ceramics, thus permanently changing both the colour of the tablets and the material evidence of manufacture. The treatment was recorded in the late $19^{\text {th }}$ century by Friedrich Rathgen (the first chemist to be employed in conservation and widely accepted as the 'father' of modern scientific conservation) and, with some modification, has continued in use (Gilberg 1987; Rathgen 1905; Thickett et al. 2002). It is still used for some tablets, although a more cautious, and less interventive, approach may be used where feasible.

The drive to preserve or protect the text, even possibly at the cost of other aspects of an object, can also be seen in the ways in which books were cared for traditionally. It was considered important to keep books in use (i.e. readable) and to do this the removal of old, worn and damaged bindings and their replacement with new ones, was a widespread and accepted practice. This kept the body of the book well protected and the text accessible; however not only was the earlier binding lost but the process of rebinding might involve other losses through practices such as trimming of pages. Recently a much more conservative approach has been adopted with existing bindings being retained and conserved wherever possible. Historically significant early bindings were not affected by this practice but many more ordinary bindings were lost, and there continues to be a potential conflict over the views of where the value lies - in the text or in the binding (Foot 1984). With similar emphasis on preserving text, in 1999 Karen Pavelka gave a paper at a conference on 'reversibility' in which she discussed the difficulties she faced as an archive conservator with responsibility for keeping archives accessible to readers. She acknowledged that she sometimes used irreversible practices such as trimming the edges of damaged and 'fraying' documents. By sacrificing some of the material (the edges) she aimed to minimise the further, and worse, damage likely to be incurred during continued handling (Pavelka 1999).

A different dilemma was posed by the discovery in 1973 of a mass of wooden writing tablets in a waterlogged context at Vindolanda Roman fort in Northumberland (Bowman 1983). Traces of writing in ink were visible but clearly fugitive, and without conservation treatment the wooden tablets would have collapsed and disintegrated (resulting, of course, in the loss of text). The normal treatment for waterlogged wood at that time involved immersion in a synthetic wax which would have darkened the wood and obscured the writing. An alternative treatment was used which involved the potentially dangerous process of heating ether (a highly flammable solvent) in order to dissolve the resin used to strengthen the wood tablets. It was possible to do this safely 
because the tablets are small and the work could be carried out under carefully controlled conditions (Blackshaw 1974). Had they been larger this treatment might not have been used. Today we would probably prefer to use a freeze-drying technique, after testing carefully to assess the effect on the text (this technique was not widely available in the 1970s). Another option open to us now would be to digitally record and disseminate the visible text before attempting conservation of the physical tablets. Thus, we might display (and preserve) the text in virtual form rather than risk affecting the materiality of the tablets themselves. Indeed, the digital documentation of visible text prior to conservation is a viable option for most, if not all, types of written document.

\section{Digital Conservation and Restoration}

For centuries, replicas or surrogates have been made of important objects, e.g. casts of famous sculptures. The aim was to provide access to people who could not see the 'real' thing. Figure 5 shows a silver decadrachm of Syracuse $\left(5^{\text {th }}\right.$ century вс) in the British Museum (Figure 5a) together with two forms of $19^{\text {th }}$-century surrogate - a silver electrotype (Figure 5b) and a moulded paper 'squeeze' (Figure 5c). For the same reasons, copies of texts have been made either as transcripts or in print. The advent of photography meant that the appearance of the text could be captured, so original texts could be conserved by limiting access and providing a photographic copy. Today, digital imaging has enormously expanded the possibilities of viewing and studying damaged and fragmentary text (MacDonald 2006).

This expanded use of digital imaging and of surrogates, has led to the use of the phrase 'digital preservation' or 'informational preservation' (Keene 2005: 138; Muñoz Viñas 2005: 23). It has changed the balance of risk and benefit since the original material is exposed to fewer risks (perhaps only the one-off manipulation needed to make a clear image) and the text becomes readily accessible. This form of conservation is now in common use for newspapers (which, being printed on low-grade paper, deteriorate very readily; British Library 2009a). Today's newspaper is replaced with tomorrow's surrogate, and only selected examples of the original newspaper are kept for evidence and legal reasons (put into permanent, controlled and, effectively, inaccessible storage).

Perhaps the most remarkable example of a major document now digitally imaged, virtually reunited, and accessible on a dedicated website is the Codex Sinaiticus. This is the earliest surviving copy of the Christian Bible and one of the earliest known bound books, different parts of which are held in different institutions (in Egypt, Germany, Russia, and the UK). On the website there is information about the conservation needed to prepare for imaging, and it is possible to view the pages in both normal and raking light, displaying a realistic impression of their condition (raking light throws surface topography into visible relief thus giving an indication of the materiality of both text and substrate; Codex 2009).

Furthermore, digital imaging, particularly 3D imaging, has introduced the possibilities of digital investigation and digital restoration. Details of text can be digitally enhanced and the image, or the $3 \mathrm{D}$ virtual model, can be moved or rotated to achieve a better view - all without manipulation or damage to the material original. This is particularly useful with cuneiform tablets as they are cushion-shaped with the text often running over the edge and onto the rounded sides making it impossible to view all the text in the same plane (Hahn et al. 2006; Kumar et al. 2003). Whereas hitherto the only way to enhance text was to modify the original object (e.g. white paint applied to the lettering on the Rosetta Stone as recently as 1981, see British Museum 2009), digital imaging can be used to enhance lettering without touching the original. This has been used on fragmentary papyri, and has the potential to aid matching up and repositioning separated fragments (Sparavigna 2009). Reflectance Transformation Imaging (RTI) is also being used to flesh out the 


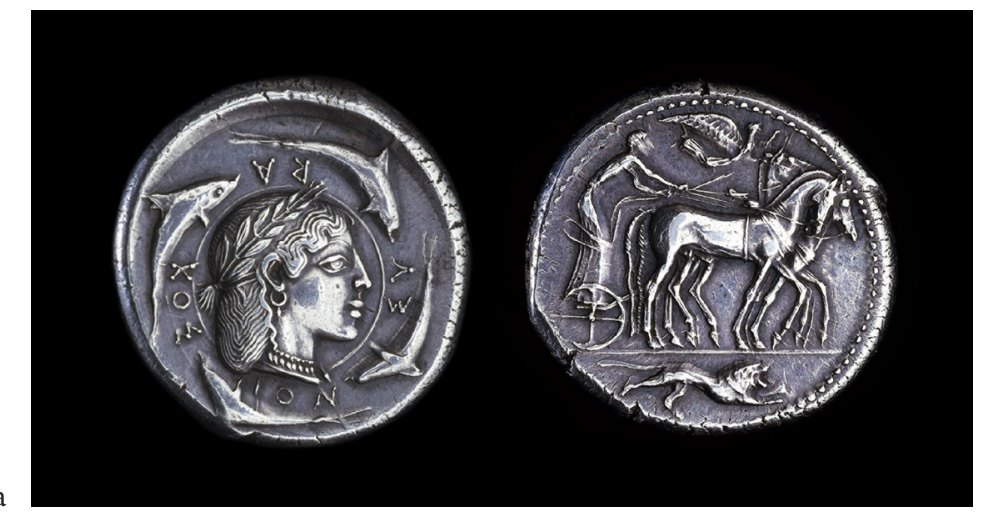

$\mathrm{b}$
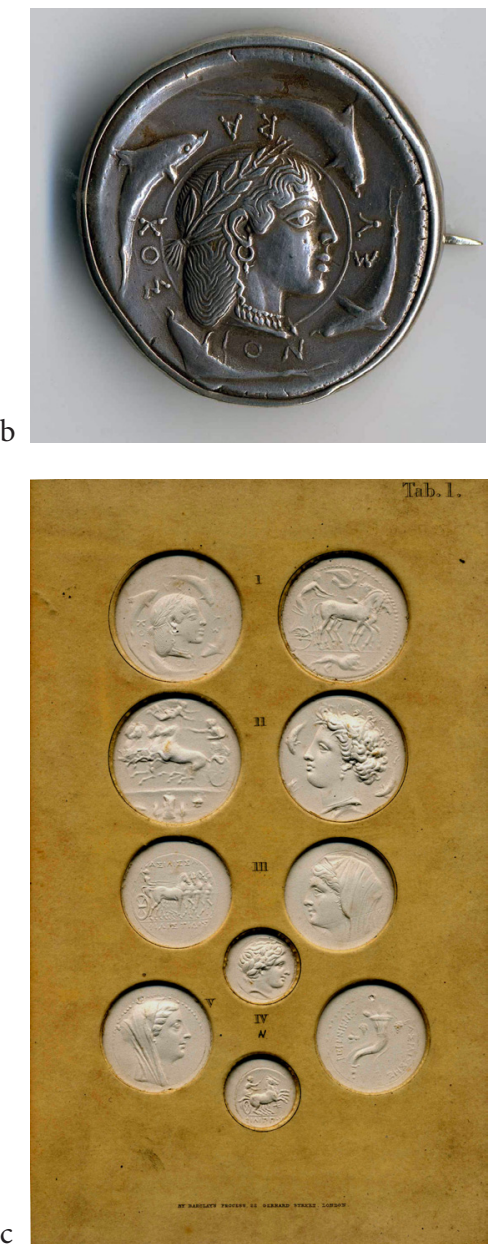

Figure 5: a) A silver decadrachm of Syracuse ( $5^{\text {th }}$ century BC) in the British Museum. CM BMC Syracuse 63. (C) Trustees of the British Museum; b) A $19^{\text {th }}$-century full-size silver electrotype (surrogate) of the same coin, subsequently made into a brooch. Photograph by Nick Balaam; c) Full-size moulded paper 'squeezes' (surrogates) taken from electrotypes of coins in the British Museum (plates accompanying Leake 1850). The same decadrachm is shown at the top of the 'page'. Photograph by Nick Balaam. 
faint inscriptions (Earl et al. 2011) and details of ductus, and tool and technique types used by past scribes (Piquette forthcoming). Furthermore, Stephen Quirke (2011) discusses the potential of using digital images for computer aided palaeography. Digital enhancement can also be used both to 'clean' stained or foxed paper and to increase definition of the written text without intervention on the material original, thus avoiding the use of washing or bleaching processes which may have limited visual success and be potentially damaging (Ramponi et al. 2005).

\section{Detecting the Presence of Text}

$\mathrm{X}$-radiography and examination under infrared or ultraviolet light have all been in use by conservators for some time to detect obscured surface detail, such as writing. Perhaps the most exciting example of detecting text, while minimising risk to the material, is represented by the work of the EDUCE project (Enhanced Digital Unwrapping for Conservation and Exploration). This uses micro CT (computerised tomography) to detect carbon ink, and thus text, obscured by folds in documents or by overlying pages, and was first used to 'virtually flatten' distorted manuscripts at the British Library. The technique shows considerable promise in detecting text within multilayered documents and may prove to be a successful means for virtually unrolling and reading the ancient scrolls from Herculaneum - but this is more difficult since many of these are, themselves, at least partially carbonised (Baumann et al. 2008; International Institute for Conservation 2009b).

\section{The Power and Potential of the 'Real Thing'}

Despite the possibilities offered by digital and other techniques for capturing, studying and reading virtual texts, the real thing is still valued and conserved. Significant examples of writing such as Dickens' novels are normally considered important for their content, and are available in recent or current print so most of us may never see the original handwritten or printed book 'in the flesh' (though it is now possible to see many texts on-line). However, the originals are conserved as the primary evidence of the author's work, and for the information they provide about how they were written, such as how the story evolved, and how often the text was revised (e.g. the first draft of Dickens' Nicholas Nickleby — see British Library 2009b).

The impact of the real thing was amply demonstrated by the exhibition held at the British Library in 2009, entitled Taking Liberties: The struggle for Britain's freedoms and rights. Almost all of the documents displayed have been widely distributed in later print but libraries and archives have conserved the originals. Displayed together, their materiality (parchment, papers of all kinds and sizes, inks, varied handwriting, and early printing) told an evocative story of attempts to secure and retain British liberties. The exhibition earned enthusiastic reviews from people moved by seeing the original documents (Ashley 2008; Taking Liberties 2009). The value attached to the 'real thing' gives particularly poignant emphasis to the tragedy of the collapse of the Cologne archive building in 2009 and the feared loss of many early documents (Icon 2009a; International Institute for Conservation 2009a).

An often quoted example of the reverence shown for the 'real thing' is the extraordinary conservation protection given to the American Declaration of Independence which is on view in the US National Archives. Since 1951 it had been protected from the damaging effects of oxygen by being sealed in an atmosphere of helium; more recently its casing has been redesigned and it is now housed in a highly sophisticated protective frame containing humidified argon (American Declaration of Independence 2009). Similar reverence is shown for the Magna Carta. In 2009 the four remaining copies of the first version (dated to 1215) were inscribed into the UNESCO Memory of the World Register. Lincoln Cathedral's copy is the only one of the four which is allowed 
to travel, and almost as much protection is given to it as to the Declaration of Independence (Icon $2009 b$ ). Of course this is a level of preservation and protection that can be accorded to only very few documents.

\section{Conclusion}

Until recently the presence of writing on an object has been given priority over other features when making conservation decisions, even if it may mean sacrifice of other material evidence. The advent of digital imaging means that both the general public and researchers may now interact with a virtual object rather than the original, and it has led to the widespread availability of virtual texts, as well as to the concept of digital preservation. However digital texts are primarily useful in deciphering written words, thus it is normally the text that is the focus of the imaging rather than other features such as margins and page edges, or bindings. Furthermore, imaging is not yet able to transmit satisfactory information about the materiality of the writing itself and of the substrate (clay, papyrus, parchment, paper, etc.). Thus digital imaging largely provides an immaterial and relatively flat view of the book or document. 3D and 2D+ imaging, such as Reflectance Transformation Imaging (RTI; e.g. Graeme et al. 2011; Piquette forthcoming;) and virtual handling of objects are rapidly developing, but even these cannot yet provide the subtle sensory information about materiality provided when we touch the real thing with our own hands (for example appreciation of surface texture, apparent temperature, weight, and so on; Prytherch and Jefsioutine 2007).

Moreover, the widespread use of digital images brings a new conservation dilemma - how to conserve the storage devices (e.g. CDs and DVDs) and the hardware and software needed to run them (e.g. Keene 2002). These are already presenting major conservation problems since the technology is developing so fast that earlier versions become rapidly obsolete and unusable, also because plastics are involved in the manufacture of hardware and disks, and many plastics are unstable. Even virtual objects and texts are vulnerable, thus the materiality of both writing and substrate continues to be of primary importance (particularly when interpreting meaning) and remains the focus of conservation practice.

\section{Acknowledgements}

I am very grateful to Claire Freer who, at my encouragement, explored aspects of this topic in an excellent Masters dissertation (Freer 2008); I am also grateful to the editors of this volume for inviting me to contribute, and to Nick Balaam who took the photographs, and read and criticised this text.

\section{References}

American Declaration of Independence 2009. Saving the National Treasures. http://www.pbs.org/ wgbh/nova/charters/case.html [accessed 30 April 2009].

Appadurai, A. (ed.) 1986. The Social Life of Things: Commodities in cultural perspective. Cambridge: Cambridge University Press.

Appelbaum, B. 1987. Criteria for Treatment: Reversibility. Journal of the American Institute for Conservation, 26(2): 65-73. DOI: http://dx.doi.org/10.2307/3179456

Ashley, M. 2008. Taking Liberties: The struggle for Britain's freedoms and rights. London: The British Library. 
Baumann, R., Porter, D. C. and Seales, W. 2008. The Use of Micro-CT in the Study of Archaeological Artifacts. In Art 2008: Proceedings of the $9^{\text {th }}$ International Conference on NDT of Art, Jerusalem, 2008, 1-9. http://212.8.206.21/article/art2008/papers/244Seales.pdf [accessed 26 February 2011].

Blackshaw, S. M. 1974. The Conservation of the Wooden Writing-Tablets from Vindolanda Roman Fort, Northumberland. Studies in Conservation 19(4): 244-246. DOI: http://dx.doi. org/10.2307/1505731

Bowman, A. 1983. The Roman Writing Tablets from Vindolanda. London: British Museum Publications.

British Library 2009a. Newspapers Digitisation Project. http://www.bl.uk/reshelp/findhelprestype/ news/newspdigproj/index.html [accessed 27 November 2013].

British Library 2009b. Charles Dickens' 'Nicholas Nickleby'. http://www.bl.uk/onlinegallery/ onlineex/englit/nickleby/ [accessed 27 November 2009].

British Museum 2009. History Uncovered in Conserving the Rosetta Stone. http://www.britishmuseum.org/explore/highlights/article_index/h/history_uncovered_in_conservin.aspx [accessed 27 November 2009].

Brooks, M., Lister, A., Eastop, D. and Bennett, T. 1996. Artifact or Information? Articulating the conflicts in conserving archaeological textiles. In Roy, A. and Smith, P. (eds), Preprints of the contributions to the Copenhagen Congress, 26-30 August 1996: Archaeological conservation and its consequences. London: International Institute for Conservation, 16-21.

Brown, M. 1998. Writing and Scripts. London: The British Library.

Caple, C. 2006. Objects: Reluctant witnesses to the past. Oxford: Routledge.

Casey, P. and Cronyn, J. 1980. Numismatics and Conservation. Durham: University of Durham, Department of Archaeology.

Centre for the History of the Book, University of Edinburgh. http://www.chb.hss.ed.ac.uk/ [accessed 26 November 2013].

Centre for the Study of the Book, Bodleian Library Oxford. http://www.bodley.ox.ac.uk/csb/ [accessed 26 February 2011].

Chabries, D., Booras, S. and Bearman, G. 2003. Imaging the Past: Recent applications of multispectral imaging technology to deciphering manuscripts. Antiquity 77: 359-373.

Codex 2009. Codex Sinaiticus: Experience the oldest Bible. www.codexsinaiticus.org [accessed 12 November 2009].

Earl, G., Basford, P. J., Bischoff, A. S., Bowman, A., Crowther, C., Hodgson, M., Martinez, K., Isaksen, L., Pagi, H., Piquette, K. E. and Kotoula, E. 2011. Reflectance Transformation Imaging Systems for Ancient Documentary Artefacts. In Dunn, S., Bowen, J. and Ng, K. (eds), EVA London 2011: Electronic Visualisation and the Arts. Proceedings of a conference held in London, 6-8 July 2011. Bristol: BCS, The Chartered Institute for IT, 147-154. http://ewic.bcs.org/category/15376 [accessed 14 March 2013].

Finkel, I. L. and Seymour, M. J. (eds) 2008. Babylon: Myth and reality. London: British Museum.

Foot, M. 1984. The Binding Historian and the Book Conservator. The Paper Conservator 8: 77-83.

Freer, C. 2008. Conserving Artefacts with Text. Unpublished MA dissertation, University College London.

Gilberg, M. 1987. Friedrich Rathgen: The father of modern archaeological conservation. Journal of the American Institute of Conservation 26(2): 105-120. DOI: http://dx.doi. org $/ 10.2307 / 3179459$

Gilberg, M. 1988. Antonio Piaggio and the Conservation of the Herculaneum Papyri. In Daniels, V. (ed.), Early Advances in Conservation. London: British Museum Publications, 1-6.

Gosden, C. and Marshall, Y. 1999. The Cultural Biography of Objects. World Archaeology 31(2): 169-178. DOI: http://dx.doi.org/10.1080/00438243.1999.9980439 
Hahn, D. V., Duncana, D. D., Baldwina, K. C., Cohen, J. D. and Purnomob, B. 2006. Digital Hammurabi: Design and development of a 3D scanner for cuneiform tablets. In Corner, B., Li, P. and Tocheri, M. (eds), Three-Dimensional Image Capture and Applications VII: Proceedings of the SPIE 6056: 130-141. DOI: http://dx.doi.org/10.1117/12.641219

Icon 2009a. Cologne Disaster Report. In Icon News September 2009. London: Institute for Conservation, 17-19.

Icon 2009b. Looking after Lincoln's Magna Carta. In Icon News September 2009. London: Institute for Conservation, 15-16.

International Institute for Conservation 2009a. Cologne Archive Collapses. News in Conservation 11, April 2009. London: International Institute for Conservation, 1.

International Institute for Conservation 2009b. Unwrapping the Hidden Past. News in Conservation 12, June 2009. London: International Institute for Conservation, 4-5.

Keene, S. 2002. Preserving Digital Materials: Confronting tomorrow's problems today. The Conservator 26(1): 93-99. DOI: http://dx.doi.org/10.1080/01410096.2002.9995181

Keene, S. 2005. Fragments of the World: Uses of museum collections. Oxford: Elsevier Butterworth-Heinemann.

Kumar, S., Snyder, D., Duncan, D., Cohen, J. and Cooper, J. 2003. Digital Preservation of Ancient Cuneiform Tablets Using 3D-scanning. In Proceedings of the Fourth International Conference on 3-D Digital Imaging and Modeling 2003. Banff, Canada: IEEE Computer Society, 326-333. DOI: http://dx.doi.org/10.1109/IM.2003.1240266

Leake, W. M. 1850. Plates of Coins to Accompany Topographical and Historical Notes on Syracuse. Transactions of the Royal Society of Literature of the United Kingdom. Second series, volume 3: 237-376.

MacDonald, L. (ed.) 2006 Digital Heritage: Applying digital imaging to cultural heritage. Oxford: Butterworth-Heinemann.

Muñoz Viñas, S. 2005. Contemporary Theory of Conservation. Oxford: Butterworth Heinemann.

Muñoz Viñas, S. 2009. Minimal Intervention Revisited. In Richmond, A. and Bracker, A. (eds), Conservation Principles, Dilemmas and Uncomfortable Truths. London: Butterworth-Heinemann in association with the Victoria and Albert Museum, 47-59.

National Archives, 2009. Domesday: Britain's finest treasure. http://www.nationalarchives.gov.uk/ domesday/ [accessed 15 November 2009].

Oddy, W. A. 1980. Conservation and the Requirements of the Scientist in Numismatics. In Casey, P. and Cronyn, J. (eds), Numismatics and Conservation. Durham: University of Durham, Department of Archaeology, 31-37.

Pavelka, K. L. 1999. Access as a Factor Contributing to Compromise in Conservation-treatment Decisions. In Oddy, A. and Carroll, S. (eds), Reversibility: Does it exist? (British Museum Occasional Paper 135). London: British Museum, 105-110.

Piquette, K. E. forthcoming. Reflectance Transformation Imaging: A new method for the digitisation and study of early Egyptian graphical culture. In Graff, G., Jiménez-Serrano, A. and Bailly, M. (eds), Préhistoires de l'écriture: iconographie, pratiques graphiques et émergence de lécrit dans l'Egypte prédynastique/Prehistories of writing: Iconography, graphic practices and the forming process of writing in Predynastic Egypt. Actes de la table-ronde de décembre 2010. Aixen-Provence: Préhistoires méditerranéennes.

Prytherch, D. and Jefsioutine, M. 2007. Touching Ghosts: Haptic technologies in museums. In Pye, E. (ed.), The Power of Touch: Handling objects in museum and heritage contexts. Walnut Creek: Left Coast Press, 223-240.

Pye, E. 2001. Caring for the Past: Issues in conservation for archaeology and museums. London: James and James.

Quirke, S. 2011. Agendas for Digital Palaeography in an Archaeological Context: Egypt 1800 BC. In Fischer, F., Fritze, C. and Vogeler, G. (eds), Kodikologie und Paläographie im digitalen 
Zeitalter 2 / Codicology and Palaeography in the Digital Age 2 (Schriften des Instituts für Dokumentologie und Editorik 3). Norderstedt: Books on Demand, 279-294.

Ramponi, G., Stanco, F., Dello Russo, W., Pelusi, S. and Mauro, P. 2005. Digital Automated Restoration of Manuscripts and Antique Printed Books. Proceedings of EVA 2005: Electronic Imaging and the Visual Arts, Florence, Italy, 14-18 March 2005. http://iplab.dmi.unict.it/download/ Elenco\%20Pubblicazioni\%20(PDF)/International\%20Conferences/EVA05.pdf [accessed 26 February 2011].

Rathgen, F. 1905. The Preservation of Antiquities (translated by G. A. Auden and H. A. Auden). Cambridge: Cambridge University Press.

Seeley, N. J. 1980. Aims and Limitations in the Conservation of Coins. In Casey, P. and Cronyn, J. (eds), Numismatics and Conservation. Durham: University of Durham, Department of Archaeology, 5-9.

Sparavigna, A. 2009. Digital Restoration of Ancient Papyri. http://arxiv.org/ftp/arxiv/ papers/0903/0903.5045.pdf [accessed 28 April 2009].

Taking Liberties 2009. Taking Liberties: The struggle for Britain's freedoms and rights. http://www. bl.uk/onlinegallery/takingliberties [accessed 30 April 2009].

Thickett, D., Odlyha, M. and Ling, D. 2002. An Improved Firing Treatment for Cuneiform Tablets. Studies in Conservation 47(1): 1-11. DOI: http://dx.doi.org/10.2307/1506830

Vlachou, C., McDonnell, J. and Janaway, R. 2003. The Investigation of Degradation Effects in Silvered Copper Alloy Roman Coins. In Townsend, J., Eremin, K. and Adriaens, A. (eds), Conservation Science 2002. London: Archetype, 236-241.

Williams, S. L. 1997. Preventive Conservation: The evolution of a museum ethic. In Edson, G. (ed.), Museum Ethics. London and New York: Routledge, 198-206. 